\title{
Neuropeptide $Y$ in the basolateral amygdala modulates the acquisition of conditioned fear
}

\author{
Ramon O Tasan ${ }^{1 *}$, Dilip Verma', Herbert Herzog ${ }^{2}$, Günther Sperk ${ }^{1}$ \\ From 16th Scientific Symposium of the Austrian Pharmacological Society (APHAR) \\ Vienna, Austria. 25-27 November 2010
}

\section{Background}

Neuropeptide Y (NPY), a highly conserved 36 amino acid peptide, is widely distributed in the central nervous system. Besides its functions in various metabolic processes NPY has attracted considerable attention in modulating emotional-affective behavior. NPY exerts a pronounced anxiolytic effect most likely mediated by $\mathrm{Y}_{1}$ receptors, whereas stimulation of predominantly presynaptic $\mathrm{Y}_{2}$ receptors results in increased anxiety. The role of NPY in the processing of fear, however, is still not conclusive. The current study aims to elucidate the role of NPY in Pavlovian fear conditioning, a simple form of associative learning.

\section{Methods}

NPY KO mice as well as KO mice for the different NPY receptors $\left(\mathrm{Y}_{1}, \mathrm{Y}_{2}\right.$ and $\left.\mathrm{Y}_{4}\right)$ were subjected to a delay fearconditioning paradigm (5 tone/shock pairings), followed by an extinction session $24 \mathrm{~h}$ later (40 tone alone presentations).

\section{Results}

NPY KO mice revealed faster acquisition and excessive expression of conditioned fear. Baseline freezing was increased on retention/extinction day and the ability to distinguish an explicitly paired tone from an unpaired tone was limited, both indications for a generalization of conditioned fear. Moreover, NPY KO mice displayed a pronounced deficit in the extinction of fear memory. Within session, extinction as well as extinction recall were significantly impaired in NPY KO mice. Expression of NPY by an AAV-vector in the basolateral amygdala (BLA) partly ameliorated deficits seen in NPY KO mice. $\mathrm{Y}_{1} \mathrm{KO}$ mice

\footnotetext{
* Correspondence: ramon.tasan@i-med.ac.at

${ }^{1}$ Institute of Pharmacology, Innsbruck Medical University, 6020 Innsbruck, Austria

Full list of author information is available at the end of the article
}

showed increased acquisition and delayed extinction, whereas no obvious phenotype was seen in $\mathrm{Y}_{2} \mathrm{KO}$ mice. $\mathrm{Y}_{4}$ $\mathrm{KO}$ mice exhibited a significant deficit in fear extinction.

\section{Conclusions}

Our data indicate that NPY in the BLA exerts a protective role in the acquisition of fear memories. In addition, it facilitates extinction of conditioned fear. Experiments performed in $\mathrm{Y}$ receptor $\mathrm{KO}$ mice suggest a prominent role of the $Y_{1}$ receptor in acquisition and extinction of conditioned fear, whereas $\mathrm{Y}_{4}$ receptors seem to be involved in extinction learning.

\section{Author details}

${ }^{1}$ Institute of Pharmacology, Innsbruck Medical University, 6020 Innsbruck, Austria. ${ }^{2}$ Neuroscience Research Program, Garvan Institute of Medical Research, Darlinghurst NSW 2010, Australia.

Published: 16 November 2010

doi:10.1186/1471-2210-10-S1-A33

Cite this article as: Tasan et al:: Neuropeptide $Y$ in the basolateral amygdala modulates the acquisition of conditioned fear. BMC

Pharmacology 2010 10(Suppl 1):A33.

Submit your next manuscript to BioMed Central and take full advantage of:

- Convenient online submission

- Thorough peer review

- No space constraints or color figure charges

- Immediate publication on acceptance

- Inclusion in PubMed, CAS, Scopus and Google Scholar

- Research which is freely available for redistribution 